\title{
Characterization of native plant growth-promoting bacteria (PGPB) and their effect on the development of maize (Zea mays L.)
}

\author{
Caracterización de bacterias promotoras de crecimiento vegetal (BPCV) nativas y su efecto \\ en el desarrollo del maíz (Zea mays L.)
}

\author{
Carlos Fernando Amezquita-Aviles', Claudia Brizeida Coronel-Acosta', Sergio de los Santos-Villalobos', Gustavo \\ Santoyo ${ }^{2}$, Fannie Isela Parra-Cota ${ }^{3 *}$ \\ Instituto Tecnológico de Sonora, Cd. Obregón, Sonora, México \\ Instituto de Investigaciones Químico Biológicas, Universidad Michoacana de San Nicolás de Hidalgo, Morelia, México \\ Campo Experimental Norman E. Borlaug-INIFAP. Norman Borlaug km 12, Cd. Obregón, Sonora, México.
}

\section{ABSTRACT}

Maize (Zea mays L.) is one of the most important cereals for Mexico and humanity. The Yaqui Valley -located at the northwest of Mexico- is one of the most important agricultural regions worldwide, it is characterized by an indiscriminate use of inorganic fertilizers for improving crop yields, leading to an increased environmental and economic cost of maize production. This work carried out a morphological, metabolic, and molecular characterization of native bacteria associated with maize rhizosphere, evaluating the positive effects of bacterial inoculation on plants under greenhouse conditions. The evaluated strains were taxonomically affiliated -based on the 16S rRNA gene- as Bacillus sp. (13B41), Advenella incenata (22A67), Pantoea dispersa (22B45), and Rhizobium pusense (31B11). All these strains were able to synthesize indoles, produce siderophores, and solubilize phosphates. The individual inoculation of these strains to maize plants showed a significant increment (compared to un-inoculated plants) in height (35-40\%), shoot dry weight (244-289\%), root dry weight (99-137\%), and SPAD values (40- $47 \%$ ). The native bacteria associated with maize in the Yaqui Valley are a promising alternative to promote the growth of their host plant and contribute to a sustainable maize production.

Keywords: microbial inoculants, plant growth promotion, soil, greenhouse.

\section{RESUMEN}

El maíz (Zea mays L.) es uno de los cereales más importantes para México y la humanidad. El Valle del Yaqui -ubicado en el noroeste de México- es una de las regiones agrícolas más importantes a nivel mundial, se caracteriza por un uso indiscriminado de fertilizantes inorgánicos para mejorar el rendimiento de los cultivos, lo que genera un mayor costo ambiental y económico de la producción de maíz. En este trabajo se realizó una caracterización morfológica, metabólica y molecular de bacterias nativas asociadas a la rizósfera del maíz y se evaluaron los efectos positivos de la inoculación bacteriana en plantas de maíz bajo condiciones de invernadero. Basándose en la secuencia del gen del $16 \mathrm{~S}$ ARNr las cepas evaluadas se afiliaron taxonómicamente como Bacillus sp. (13B41), Advenella incenata (22A67), Pan- toea dispersa (22B45) y Rhizobium pusense (31B11). Todas estas cepas pudieron sintetizar indoles, producir sideróforos y solubilizar fosfatos. La inoculación individual de estas cepas en maíz mostró un incremento significativo (en comparación con plantas no inoculadas) en altura (35-40\%), peso seco de brotes (244-289\%), peso seco de raíces (99-137\%) y valores SPAD (40-47\%). Las bacterias asociadas al maíz nativas del Valle del Yaqui son una alternativa prometedora para promover el crecimiento de su planta hospedante y contribuir a una producción de maíz sostenible.

Palabras clave: inoculantes microbianos, promoción del crecimiento vegetal, suelo, invernadero.

\section{INTRODUCTION}

Maize (Zea mays L.) belongs to the group of cereals with worldwide importance, due to its applications in animal consumption, including human. In 2018, world maize production reached 1147.62 million tons, the highest amount among the main cereals (FAO, 2020). In Mexico, during 2018, around 7.3 million hectares were cultivated with this cereal, with a total production of 27.1 million tons (SIAP-SADER, 2020). On the other hand, maize production in the main agricultural zones of northwestern Mexico, such as the Yaqui Valley, reached 449,000 tons in the year 2018, while in 2019 its production increased up to 567,000 tons (SIAP-SADER, 2020). However, this global and national food demand has led to the indiscriminate use of agrochemicals, in areas of intensive agriculture such as the Yaqui Valley, where high amounts of nitrogen and phosphate fertilizers have been used, as well as pesticides, to improve the yield of several crops such as wheat and maize (McCullough and Matson, 2016). Nevertheless, the excessive use of agrochemicals contributes to the contamination of soils and underground water supplies, leading to potential health risks and environmental degradation (Meza-Montenegro et al., 2012). Thus, the need fo the development of sustainable strategies for food production, to diminish the damage caused by the use of large quantities of agrochemicals, is evident.

The use of soil microorganisms (mainly bacteria) as inoculants with beneficial traits for plant development and soil health represents an attractive alternative to conven- 
tional agriculture, named Plant Growth Promoting Bacteria (PGPB) (Valenzuela-Aragon et al., 2019). PGPB includes a large group of microorganisms that can be found in the rhizosphere and bulk soil, as well as within and on aerial plant tissues (de Souza et al., 2015). PGPB applied to plants, either on soil or seeds, improve plant crops growth and protection against diseases and abiotic stress, by improving the biological nitrogen fixation, solubilization of phosphates, reduction of stress through diverse enzyme production, synthesis of phytohormones, production of siderophores, among others (Glick, 2012; de Souza et al., 2015). Thus, the most studied genera of PGPB are Acetobacter, Acinetobacter, Alcaligenes, Arthrobacter, Azospirillum, Azotobacter, Bacillus, Bradyrhizobium, Burkholderia, Enterobacter, Gluconacetobacter, KlebsieIla, Methylobacterium, Ochrobactrum, Paenibacillus, Pantoea, Pseudomonas, Serratia, Stenotrophomonas, and Rhizobium (Glick, 2012; Ahemad and Kibret, 2014). Several studies have demonstrated the ability of these bacterial genera to promote the growth of different crops such as rice, tomato, wheat, maize, chickpea, peanuts, among others, showing significant changes in physiological parameters, i.e., dry weight, chlorophyll content, and plant height (Kumar et al., 2014; Sharon et al., 2016).

PGPB can be classified as native or indigenous when those are endemic to the site where they will be applied and as exogenous when they are isolated from other locations. Several research, mainly related to pollutants biodegradation, have shown that for an exogenous PGPB to properly perform its functions, not only must adapt to the local region edaphoclimatic conditions but also there must be compatibility with the native microorganisms (i.e. to avoid competence for nutrients or a specific niche). For example, Festa et al. (2016) found that the inoculation of exogenous microorganisms caused significant changes in the diversity of the microbial community, which can compromise the subsequent functionality of the soil. On the other hand, Kaur and Reddy (2013) demonstrated that native bacterial strains associated with maize crop have the ability to facilitate microorganism-plant interaction in order to enhance plant growth parameters, such as shoot length, germination, shoot, and root dry weight, as well as an increase in crop yield, by the production of phytohormones, siderophores, and solubilization of phosphates. However, the bacterial inoculant success in the field is not assured, due to the influence of several important factors such as climatic conditions, native microbiota, and its formulation (Dutta and Podile, 2010; de los Santos-Villalobos et al., 2018). The introduction of exogenous PGPB could induce at least a transient perturbation of the equilibrium of soil microbial communities, this may be undesirable if important native species are lost, affecting subsequent crops (Trabelsi and Mhamdi, 2013). However, this effect could be buffered by ecosystem resilience, which is driven by the level of diversity and interactions of the plant-soil-biota (Kennedy, 1999).

At present, research works on native microbiota in the Yaqui Valley are very scarce (de los Santos-Villalobos et al., 2018), even when this is the birthplace of the Green Revolution, and there are no microbial inoculants developed with native strains from this area, which have adapted to the edaphoclimatic conditions (high temperatures, alkaline and low content of organic matter). The aim of this study was to identify and characterize promising native PGPB associated with maize in the Yaqui Valley, as well as to quantify their inoculating impact on morphometric parameters of maize, grown under greenhouse conditions.

\section{MATERIALS AND METHODS Bacterial strains}

The studied bacterial strains (22A67, 13B41, 22B45, and $31 \mathrm{~B} 11$ ) were selected according to their ability to promote in vitro maize growth (unpublished data). These strains are cryopreserved in Colección de Microorganismos Edáficos y Endófitos Nativos (COLMENA, www.itson.mx/COLMENA) (de los Santos-Villalobos et al., 2018). Glycerol-frozen $\left(-80^{\circ} \mathrm{C}\right)$ bacterial strains were pre-cultured in Petri dishes containing Nutrient Agar (NA) as a culture medium, and incubated for $24 \mathrm{~h}$ at $28^{\circ} \mathrm{C}$.

\section{Morphological and molecular characterization}

All bacterial strains were cultured in Nutrient Agar (NA) and incubated for $24 \mathrm{~h}$ at $28^{\circ} \mathrm{C}$ to characterize them by macro (color, shape, margins, and elevation) and microscopical (Gram stains and shape) traits. DNA from each strain axenic bacterial culture was extracted using the UltraClean Microbial DNA Isolation Kit (QIAGEN ${ }^{\circledR}$ ), the DNA integrity analyzed by $1 \%$ agarose electrophoresis while the quality and concentration by spectrophotometry (NanoMicro-Spectrophotometer Jenway ${ }^{\oplus}$ ). To amplify the $16 \mathrm{~S}$ rRNA gene $(1500 \mathrm{bp})$ we used the FD1 (5'-CCGAATTCGTCGACAACAGAGTTTGATCCTGGCTCAG-3') and RD1 (5'-CCCGGGATCCAAGCTTAAGGAGGTGATCCAGCC-3') primers (Weisburg et al., 1991), in a $50 \mu \mathrm{L}$ PCR reaction mixture containing 100 ng DNA, 1X PCR buffer, $0.2 \mu \mathrm{M}$ primers, and $4 \mathrm{U}$ MyTaq DNA polymerase (Bioline). The PCR cycle was as follows: $5 \mathrm{~min}$ at $95^{\circ} \mathrm{C}$, followed by 30 cycles of $30 \mathrm{~s}$ at $95^{\circ} \mathrm{C}, 40 \mathrm{~s}$ at $57^{\circ} \mathrm{C}, 2 \mathrm{~min}$ at $72{ }^{\circ} \mathrm{C}$, and a final elongation step of $5 \mathrm{~min}$ at $72{ }^{\circ} \mathrm{C}$. PCR products were verified by electrophoresis gel agarose/TAE (2\%), and the purified amplicons sequenced by the Sanger platform. The edition and analysis of the obtained DNA sequences was with the software FinchTV 1.4.0 (Geospiza, Seattle, WA), CLC Sequence viewer 7 (QIAGEN, Denmark), and BLAST (NCBI, www.ncbi. nlm.nih.gov) used to identify the reported sequence with greater similarity to the studied bacterial strains. The phylogenetic analysis was generated with the MEGA software version 7.0 (Kumar et al., 2016) using the neighbor-joining method, the evolutionary distances computed using the Tamura 3-parameter model. The partial sequences of the $16 \mathrm{~S}$ rRNA gene were deposited in the Genbank database (MG807394, MG807395, MG807396, MG807397 accession numbers). 
Plant growth promoting traits by bacterial strain

Indoles production. For quantification of indoles production, $1 \times 10^{3}$ Colony Forming Units (CFU) of each bacterial strain were inoculated, in triplicate, into $30 \mathrm{~mL}$ of nutrient broth (NB), supplemented with $100 \mathrm{ppm}$ of tryptophan, and incubated in a rotary shaker (Yamato ${ }^{\circledR}$ ) at $150 \mathrm{rpm}$ and $28{ }^{\circ} \mathrm{C}$ for 3 days. After incubation, the bacterial culture was centrifuged at $10,000 \mathrm{rpm}$ for $10 \mathrm{~min}$, and $1 \mathrm{~mL}$ of the supernatant was placed in a $1.5 \mathrm{~mL}$ Eppendorf tube and centrifuged again at $8000 \mathrm{rpm}$ for $10 \mathrm{~min}$ according to de los Santos-Villalobos et al. (2013). Quantification of indoles was performed by the spectrophotometric method using Salkowski reagent according to Glickmann and Dessaux (1995). The concentrations of produced indoles were estimated with a standard curve of indole-3-acetic acid (Sigma ${ }^{\circledR}$ ), in a range of 2-50 ppm. The tests were carried out in triplicate.

Phosphate solubilization. Each bacterial strain $\left(1 \times 10^{3}\right.$ CFU) was inoculated, in triplicate, on Petri dishes containing Pikovskaya (PVK) medium and incubated at $25^{\circ} \mathrm{C}$ for 10 days. The PVK medium was composed of 2 solutions (salts and bromophenol blue Stock) according to Onyia and Anyanwu (2013). The ability of the studied strains to solubilize phosphorus $(P)$ was observed by a transparent halo around the bacterial colony. The Phosphate solubilization index (PSI) was obtained according to Sharon et al. (2016), following the Equation 1:

Phosphate solubilization or siderophore production index $=\frac{\text { (Halo zone+Colony diameter })}{\text { Colonydiameter }}$

Equation 1. Phosphate solubilization index or Siderophore production index

Siderophore production. To determine the ability of studied bacterial strains to produce siderophores, $1 \times 10^{3} \mathrm{CFU}$ of each strain was inoculated on Petri dishes containing chrome azurol $\mathrm{S}$ medium (CAS), and incubated at $28^{\circ} \mathrm{C}$ for 10 days, by three independent replicates (García-Meléndez et al., 2017). The CAS medium preparation was following the method described by Alexander and Zuberer (1991). Strains that showed a transparent or colored halo around the bacterial colony were positive for this test. The siderophore production index was obtained following the Equation 1.

1-Aminocyclopropane-1-Carboxylate(ACC) deaminase activity. The ability of strains to produce ACC deaminase was screened in Petri dishes containing minimal medium according to Dworking and Foster (1958). $1 \times 10^{3}$ CFU of each strain was inoculated, by triplicate, in Petri dishes containing minimal media with ACC as its sole nitrogen source; then incubated at $28^{\circ} \mathrm{C}$ for 3 days. Bacterial growth in the minimal medium was considered positive in ACC deaminase activity (nutrient medium was used as control).

In all the characterization tests mentioned above, Bacillus sp. P41B2 whose plant growth promoting traits are known was used as technical control.
Maize growth promotion by studied PGPB under greenhouse conditions

Bacterial production. A bacterial pre-inoculum was prepared for each strain ( $1 \times 10^{5}$ UFC), in tubes with $25 \mathrm{~mL}$ of Nutrient Broth (NB), incubated at $120 \mathrm{rpm}$ for $24 \mathrm{~h}$ at $28^{\circ} \mathrm{C}$. Then, the pre-inoculum optical density adjusted to $\mathrm{OD}_{630}=0.5$ (Valenzuela-Aragon et al., 2019). For the bacterial inoculum, $1 \mathrm{~mL}$ of pre-inoculum was inoculated to $3 \mathrm{~L}$ of NB , and incubated for $72 \mathrm{~h}$, at $28^{\circ} \mathrm{C}$ with shaking at $120 \mathrm{rpm}$. The bacterial suspension was pelleted by centrifugation for $15 \mathrm{~min}$ at 4000 rpm, washed twice and finally re-suspended in sterile distilled water. The bacterial concentration (CFU/mL) was adjusted to $1 \times 10^{9} \mathrm{CFU} / \mathrm{mL}$.

Greenhouse assay. The greenhouse assay was carried out in $4 \mathrm{~L}$ pots under greenhouse conditions at the Instituto Nacional de Investigaciones Forestales, Agrícolas y Pecuarias (INIFAP) located at Cajeme, Sonora $\left(27^{\circ} \mathrm{N}, 110^{\circ} \mathrm{W}\right)$. The max/ min temperature during assay was $30^{\circ} \mathrm{C} / 8{ }^{\circ} \mathrm{C}$ and 12 -hour photoperiod. CARIBU ${ }^{\circledast}$ (ASGROW ${ }^{\circledR}$ ) commercial hybrid maize was used. A non-sterile mixture of perlite/agricultural soil/ Pro-Mix GTX ${ }^{\circledR}$ substrate (1:3:2) was used as a plant substrate. The soil mixture was classified as clay-loam, with the follow-

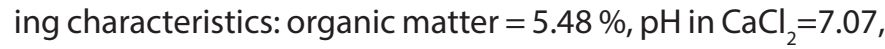
electrical conductivity $=2.903 \mathrm{dS} / \mathrm{m}$, total salts $=1858 \mathrm{ppm}$, $\mathrm{N}=217 \mathrm{Kg} / \mathrm{Ha}, \mathrm{P}=15 \mathrm{ppm}$. In each pot, $300 \mathrm{~mL}\left(1 \times 10^{9} \mathrm{CFU} /\right.$ $\mathrm{mL}$ ) of each bacterial strain were applied separately to each plant, 10 replicates per treatment and an un-inoculated control were established. Plants were kept well-watered, and no chemical fertilizers were applied during the assay (Parra-Cota et al., 2014).

Measurement of maize growth parameters. Data collection was weekly over 6 weeks and at the end of the assay (42 days after sowing). The first measurement was 14 days after sowing between stages V3 and V4 of maize growth. Plant height, leaf chlorophyll level (SPAD 502 Minolta ${ }^{\circledR}$ ), and leaves number were measured, and at the end, height, plant and root dry weight, and stem thickness.

\section{Statistical analysis}

A completely randomized design was applied in all experimental assays with three replicates per treatment, in the greenhouse assay a replicate was constituted by 10 . Data analysis was by one-way analysis of variance (ANOVA) test and Tukey-Kramer test $(p=0.05)$, using Statgraphics Centurion XVI.II (Statgraphics Technologies, Inc., Virginia).

\section{RESULTS AND DISCUSSION}

\section{Morphological and molecular characterization of studied bacterial strains}

The macroscopic traits of all strains were similar in shape (circular), margin (entire), and elevation (flat) but different colors. Cell shape varied from coccus for strain 22A67 to rod-shaped for the other strains. Similarly, Gram stain was different between the bacterial strains (Table 1). Based on the $16 \mathrm{~S}$ rRNA gene sequence phylogenetic analysis (Figure 1), the identifications were as follows: strain $22 \mathrm{A67}$ as Advenella incenata (MG807395, accession number), strain 22B45 
Table 1. Morphological characteristics of studied PGPB.

Tabla 1. Características morfológicas de las BPCV estudiadas.

\begin{tabular}{|ccccc}
\hline Strain & \multicolumn{2}{c}{ Macroscopic traits } & \multicolumn{2}{c}{ Microscopic traits } \\
& Morphological traits & Color & Cell shape & $\begin{array}{c}\text { Gram } \\
\text { reaction }\end{array}$ \\
\hline 13B41 & $\begin{array}{c}\text { Circular with entire } \\
\text { margin and flat }\end{array}$ & Brown & Rod-shaped & Positive \\
\hline 22A67 & $\begin{array}{c}\text { Circular with entire } \\
\text { margin and flat }\end{array}$ & $\begin{array}{c}\text { Light } \\
\text { Brown }\end{array}$ & Coccus & Negative \\
\hline 22B45 & $\begin{array}{c}\text { Circular with entire } \\
\text { margin and flat }\end{array}$ & Yellow & Rod-shaped & Negative \\
\hline 31B11 & $\begin{array}{c}\text { Circular with entire } \\
\text { margin and flat }\end{array}$ & Brown & Rod-shaped & Negative \\
\hline
\end{tabular}

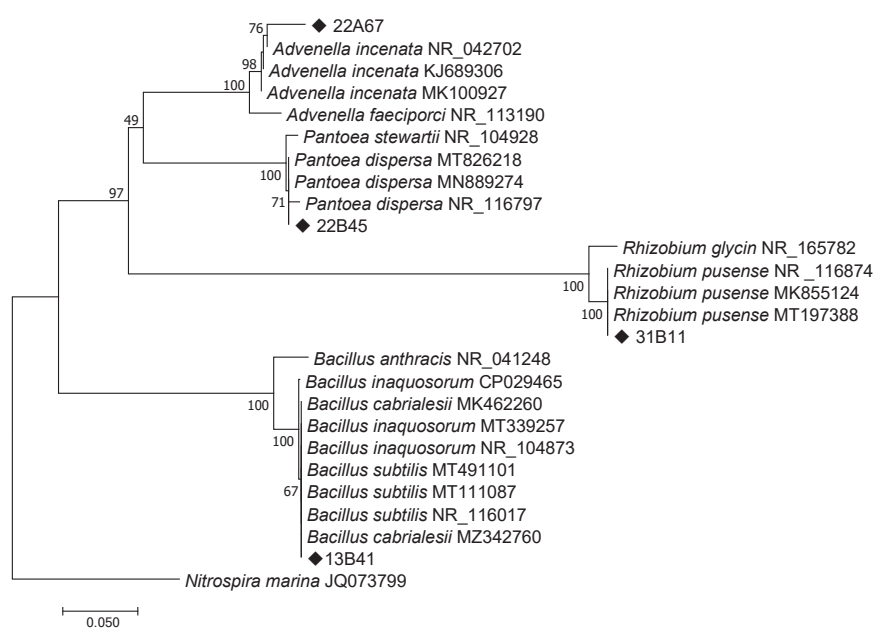

Figure 1. Phylogenetic Tree inferred using the Neighbor-Joining method. Numbers at nodes indicate values of bootstrap support based on an analysis of 1,000 resampled data sets. Nitrospira marina was used as an outgroup sequence. The scale bar indicates the number of base substitutions per site. Figura 1. Árbol filogenético inferido mediante el método de NeighborJoining. Los números en los nodos indican valores de soporte de bootstrap basados en un análisis de 1000 conjuntos de datos remuestreados. Se utilizó Nitrospira marina como secuencia externa. La barra de escala indica el número de sustituciones de bases por sitio.

as Pantoea dispersa (MG807397), strain 31B11 as Rhizobium pusense (MG807394), and the strain 13B41 (MG807396) as Bacillus sp. In the latter, it was not possible to determine the species due to the sequences high similarity between different species of the genus Bacillus.

The four genera to which the studied bacterial strains belong have been previously described as PGPB. The Bacillus genus was first reported by Cohn in 1872 and currently includes more than 377 species, which are widely distributed in very diverse ecosystems such as aquatic, terrestrial, and those with extreme conditions (Villarreal-Delgado et al., 2018; de los Santos Villalobos et al., 2019). Several Bacillus species have been identified as plant growth-promoting bacteria since they suppress pathogens and/or improve plant development (Sansinenea, 2019). Bacteria of the Rhizobium genus have been extensively studied for their ability to fix nitrogen in symbiosis with legumes, but Rhizobium is also a very good root colonizer of non-legumes and can produce plant hormones, siderophores, solubilize phosphorus, and exhibits adverse effects to plant pathogens (Qureshi et al., 2013). At present, many research works have demonstrated the beneficial effects of Rhizobium inoculation to cereals, like maize, in terms of improved growth and yield (Mehboob et al., 2012; Hussain et al., 2016).

Pantoea is a relatively recent genus, proposed by Gavini et al. (1989). Pantoea spp. have been isolated from plants surfaces, within plant tissues, seeds, fruits, rhizosphere, water, soil, from humans and other animals; they are rarely considered as pathogens (Chauhan et al., 2015). Various studies have reported strains of Pantoea as biological control agents and as growth promoter in crops such as corn, wheat, apple, cotton, barley, and potato (Montañez et al., 2012; Kaur and Reddy, 2013; Chauhan et al., 2015). Whereas the genera mentioned above has been widely studied, mainly Bacillus and Rhizobium, Advenella is a poorly studied genus, and reports of their role as PGPB are scarce, but these coincide in their potential role as phosphate solubilizers in soils with crops such as maize and wheat (Espinosa-Victoria et al., 2009; Singh et al., 2014; Wang et al., 2020).

\section{Plant growth promoting traits by studied bacterial stra- ins}

In order to have a better understanding of plantmicroorganism interactions, it is important to study the PGPB potential mechanisms of action. The four studied strains were able to produce indoles, i.e., Pantoea dispersa 22B45 showed the higher production of indoles (11 ppm), followed by BaciIlus sp. 13B41 (4.0 ppm), Rhizobium pusense 31B11 (3.8 ppm), and Advenella incenata 22A67 (2.8 ppm) (Table 2). Indole acetic acid (IAA) is generally considered as the most important native auxin (Glick, 2012); several species of bacteria are capable to produce this class of phytohormones, where their production vary depending on growing conditions, stage of development, availability of nutrients, among others (Duca et al., 2014). The bacteria indoles production can affect the hormonal balance in plants and, therefore, can influence their growth, mainly increasing the total root surface, which leads to an enhanced mineral uptake from the soil (Spaepen and Vanderleyden, 2011). For example, in different studies, two native Pantoea strains associated with maize showed the ability to synthesize indoles in $121.6 \mathrm{ppm}$ and $93 \mathrm{ppm}$, respectively (Montañez et al., 2012; Kaur and Reddy, 2013). Similarly, Naveed et al. (2014) demonstrated that indolesproducing bacteria application can positively affect different growth parameters of maize, such as root dry weight and plant height, with increments of $43 \%$ and $8 \%$, respectively, compared to un-inoculated control.

On the other hand, Advenella incenata 22A67 showed a high level of phosphate solubilization in PVK medium, similar to an Advenella strain with phytase activity reported by Singh (2014). Pantoea dispersa 22B45, Bacillus 13B41, and Rhizobium pusense 31B11, also showed the ability to solubilize phosphates, but at a lower level (Table 2). $\mathrm{P}$ is an 
Table 2. Plant growth promotion traits by studied PGPB, under in vitro conditions.

Tabla 2. Rasgos de promoción del crecimiento vegetal de las PGPB estudiadas, en condiciones in vitro.

\begin{tabular}{ccccc}
\hline Strain & $\begin{array}{c}\text { Indoles } \\
\text { production } \\
\text { (ppm) }\end{array}$ & $\begin{array}{c}\text { Phosphate } \\
\text { solubilization } \\
\text { Index (PSI) }\end{array}$ & $\begin{array}{c}\text { Siderophore } \\
\text { production } \\
\text { Index (SPI) }\end{array}$ & $\begin{array}{c}\text { ACC } \\
\text { deaminase } \\
\text { activity }\end{array}$ \\
\hline $\begin{array}{c}\text { Bacillus sp. } \\
\text { 13B41 }\end{array}$ & $4.0^{\mathrm{b}}$ & $1.25^{\mathrm{ab}}$ & $1.88^{\mathrm{b}}$ & - \\
$\begin{array}{c}\text { Advenella } \\
\text { incenata } \\
\text { 22A67 }\end{array}$ & $2.8^{\mathrm{a}}$ & $1.58^{\mathrm{b}}$ & $1.40^{\mathrm{a}}$ & - \\
$\begin{array}{c}\text { Pantoea } \\
\text { dispersa } \\
\text { 22B45 }\end{array}$ & $11.4^{\mathrm{c}}$ & $1.42^{\mathrm{ab}}$ & $1.29^{\mathrm{a}}$ & + \\
$\begin{array}{c}\text { Rhizobium } \\
\text { pusense } \\
\text { 31B11 }\end{array}$ & $3.8^{\mathrm{b}}$ & $1.15^{\mathrm{a}}$ & $1.30^{\mathrm{a}}$ & + \\
\hline $\begin{array}{c}\text { Bacillus sp. } \\
\text { P41B2* }\end{array}$ & $3.1^{\mathrm{ab}}$ & $1.28^{\mathrm{ab}}$ & $1.37^{\mathrm{a}}$ & - \\
\hline
\end{tabular}

Different letters indicate significant differences ( $p<0.05$, Tukey- Kramer test), $n=3$. $(+)=$ Production, $(-)=$ No production. ${ }^{*}=$ Technical control

important nutrient of plants due to it is involved in different functions, such as photosynthesis, respiration, and nutrient movement (Viruel et al., 2014). There is enough P in soil, but only a small amount is available for plants, which limits their growth (Viruel et al., 2014). The P availability depends on its solubility, which is influenced by the activity of roots and microorganisms in the soil, mainly through the production of organic acids and alternate mechanisms as the production of chelating compounds and secretion of phytase enzymes (Pande et al., 2017). Thus, the studied strains can be classified as phosphate-solubilizing bacteria capable of solubilizing phosphate from an insoluble tricalcium source, which has shown a positive impact on biomass weights of tomato and maize crops, compared to un-inoculated plants (Montañez et al., 2012; Sharon et al., 2016).

Another important micronutrient for plants is iron (Fe), which influences several important biological processes such as photosynthesis, respiration, and chlorophyll synthesis (Kobayashi and Nishizawa, 2012). However, like phosphorus, this micronutrient has low availability in soils. Soil bacteria can overcome this Fe limitation by chelating molecules called siderophores (Villarreal-Delgado et al., 2018), which production capacity provides an advantage against soilborne pathogens (de los Santos-Villalobos et al., 2012). Every studied strains showed the ability to produce siderophores, observing the higher value (SPI=1.88) for Bacillus sp. 13B41, significantly different compared to the rest of the strains (Table 2). In addition, bacterial genera like Pantoea, Advenella, Bacillus, and Rhizobium have shown this biochemical trait, also related to the growth promotion effect in maize and wheat cultivars (Kaur and Reddy, 2013; Kumar et al., 2014; Singh et al., 2014).

The activity of the enzyme 1-aminocyclopropane1-carboxylate (ACC) deaminase, is of a plant growth promoter mechanism by microorganisms, which regulate plant levels of ethylene (Glick, 2012). Ethylene is produced endogenously by plants and participates in the regulation of all processes for their growth, however, under environmental stress, its production is accelerated, negatively affecting root growth, and therefore, the development of the whole plant (de Souza et al., 2015). Here, Pantoea dispersa 22B45 and Rhizobium pusense 31B11 showed ACC activity, like that reported by Shahzad et al. (2008), where strains of the genus Pantoea were identified with ACC activity and used to increase the yield of chickpea of up to $54 \%$ compared to the un-inoculated control. Hussain et al. (2016) showed that by the inoculation of Rhizobium in maize, plants grew under drought stress conditions, obtaining an increase of $16 \%$ and $30 \%$ in dry biomass of root and shoot, respectively, compared to un-inoculated plants.

\section{Maize growth promotion by isolated bacterial strains, under greenhouse conditions}

In this study, all inoculated treatments showed a significant difference $(p \leq 0.05)$ in plant chlorophyll level compared to the un-inoculated treatment, increased up to $40 \%$ by BaciIlus sp., $47 \%$ by Rhizobium pusense, $41 \%$ by Pantoea dispersa, and $39 \%$ by Advenella incenata at 42 days after sowing (Figure 1). However, there was no significant difference between plants inoculated with the studied strains. At 14 days after sowing, plant chlorophyll levels increased from $13 \%$ to 20 $\%$ for all inoculated plants compared to the un-inoculated treatment (Figure 2). Increased chlorophyll content by the application of PGPB might be attributed to the enhanced root size of plants by phytohormones production, as well as the solubilization and mobilization of nutrients (Qasim et al., 2017). Furthermore, the leaf chlorophyll level is markedly related to the photosynthetic capacity, which implicates a better nutrient cycling, indicating an improvement of plant growth (Croft et al., 2016).

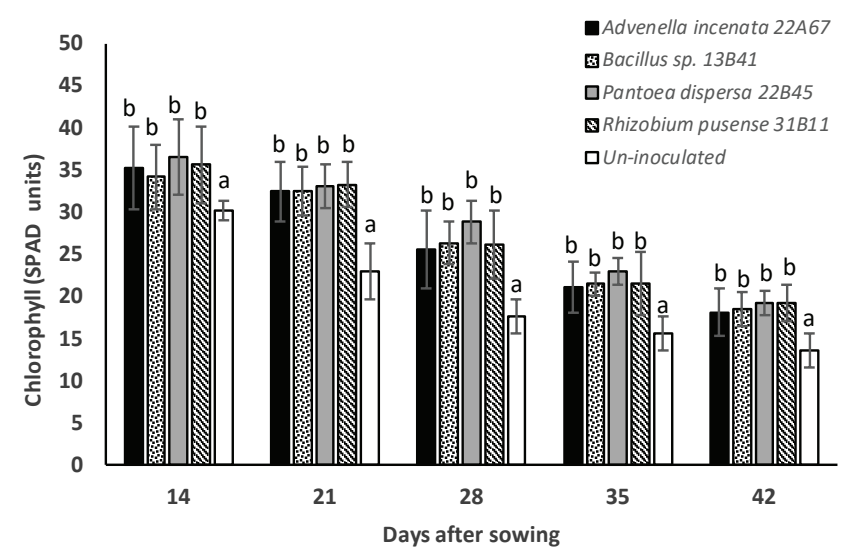

Figure 2. Chlorophyll level of maize plants inoculated by each studied strain and un-inoculated. Distinct letters indicate significant differences ( $p<0.05$, Tukey test), $n=10$.

Figura 2. Nivel de clorofila de plantas de maíz no inoculadas e inoculadas por cada cepa estudiada. Las letras distintas indican diferencias significativas ( $\mathrm{p}<0.05$, prueba de Tukey), $n=10$. 
Height of inoculated plants showed significant differences at 21 days after sowing, where strain Advenella incenata $22 \mathrm{~A} 67$ showed a height of $37 \mathrm{~cm}$, being different to the rest of the treatments $[30.2 \mathrm{~cm}, 30.9 \mathrm{~cm}, 31.5 \mathrm{~cm}$, and 28.2 $\mathrm{cm}$ for Pantoea dispersa 22B45, Rhizobium pusense 31B11, Bacillus sp. 13B41, and un-inoculated control, respectively]. The plant height on days 28,35 , and 42 after sowing, showed significant increases for all treatments $(40,51$, and $35 \%$, respectively), compared to the un-inoculated treatment, and there was no difference between plants inoculated with the studied strains, as indicated in Figure 3.

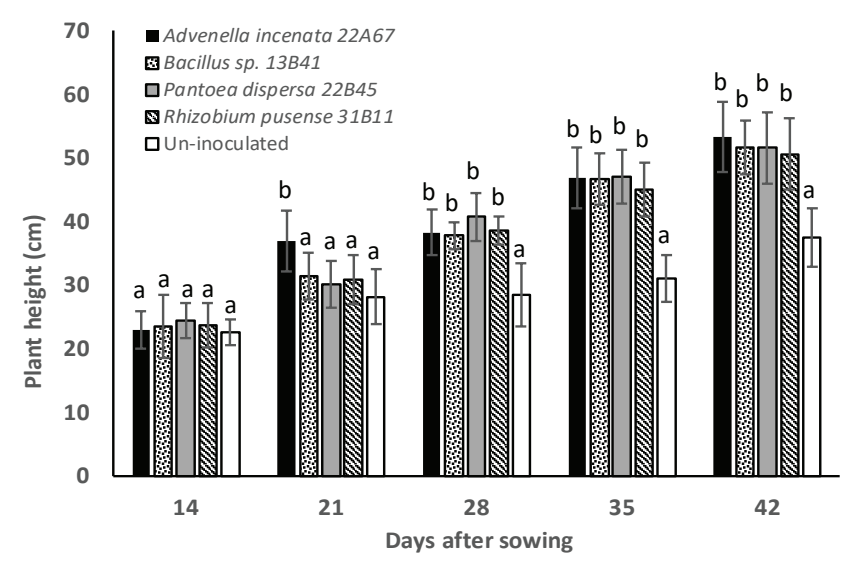

Figure 3. Height of maize plants inoculated with each strain. Distinct letters indicate significant differences ( $p<0.05$, Tukey Test), $n=10$.

Figura 3. Altura de las plantas de maíz inoculadas con cada cepa. Las letras distintas indican diferencias significativas ( $p<0.05$, prueba de Tukey), $n=10$.

In addition, the stem thickness showed a significant increment from $63 \%$ to $73 \%$ by studied bacterial strains (Table 3), compared to the un-inoculated treatment. This increment may relate to the accumulation of reserves in the stem during the vegetative stages, which could later increase the production of grains (Setter and Meller 1984; Seyed Sharifi et al., 2017). On the other hand, the maize inoculation of the studied strains increased de number of leaves, but Pantoea dispersa 22B45 increased the number of leaves by 33 $\%$, presenting at least one more leaf per plant than the rest of the strains and un-inoculated control (Table 3). Agbodjato et al. (2016) and Abiala et al. (2015) also reported an increase in the number of leaves in maize plants inoculated with PGPB under greenhouse conditions; in the first study the effect was observed by the inoculation of P. fluorescens; while in the second, the individual inoculation of Bacillus, Lysinibacillus, Citrobacter and Enterobacter caused this effect in plants. The increase in the number of leaves is clear evidence of the growth promoting effect generated by the PGPB.

Maize plants inoculated with Pantoea dispersa 22B45 also showed the highest root dry weight, $6.34 \mathrm{~g}$, followed by maize inoculated with Bacillus sp. 13B41, Rhizobium pusense 31B11, Advenella incenata 22A67, and un-inoculated plants, as shown in Table 3. All inoculated plants showed a higher shoot dry weight and root dry weight compared to the uninoculated treatment, with increments from 244 to $289 \%$,
Table 3. Effect of studied PGPB on maize growth under greenhouse conditions, at vegetative stage $\mathrm{V} 8$.

Tabla 3. Efecto de las PGPB estudiadas sobre el crecimiento del maíz en condiciones de invernadero, en la etapa vegetativa V8.

\begin{tabular}{|c|c|c|c|c|}
\hline PGPB & $\begin{array}{c}\text { Stem } \\
\text { thickness } \\
(\mathrm{mm})\end{array}$ & $\begin{array}{c}\text { Number } \\
\text { of } \\
\text { leaves }\end{array}$ & $\begin{array}{l}\text { Root dry } \\
\text { weight (g) }\end{array}$ & $\begin{array}{l}\text { Shoot dry } \\
\text { weight (g) }\end{array}$ \\
\hline $\begin{array}{c}\text { Advenella } \\
\text { incenata } \\
22 \mathrm{~A} 67\end{array}$ & $13.7 \pm 2.50^{b}$ & $8 \pm 0.79^{b}$ & $5.45 \pm 1.88^{b}$ & $7.90 \pm$ \\
\hline $\begin{array}{c}\text { Bacillus sp. } \\
13 \mathrm{~B} 41\end{array}$ & $13.6 \pm 1.71^{b}$ & $8 \pm 0.74^{b}$ & $5.99 \pm 2.10^{b}$ & $7.61 \pm$ \\
\hline $\begin{array}{c}\text { Pantoea } \\
\text { dispersa } \\
22 \mathrm{~B} 45\end{array}$ & $13.6 \pm 1.51^{b}$ & $9 \pm 0.52^{c}$ & $6.34 \pm 1.85^{b}$ & $7.89 \pm$ \\
\hline $\begin{array}{c}\text { Rhizobium } \\
\text { pusense 31B11 }\end{array}$ & $12.9 \pm 2.38^{b}$ & $8 \pm 0.82^{b}$ & $5.32 \pm 1.94^{b}$ & $6.99 \pm$ \\
\hline Un-inoculated & $1.37^{\mathrm{a}}$ & $6 \pm 0.48^{a}$ & $2.67 \pm 0.81^{a}$ & $2.03 \pm$ \\
\hline
\end{tabular}

Mean with different letters in the same column show significant difference at $p<0.05$ (Tukey-Kramer) $n=10$.

and 99 to $137 \%$, respectively (Table 3). Silva et al. (2016) reported the capacity of Pantoea and Bacillus to increase shoot and root dry matter by $28 \%$ and $18 \%$, respectively, in maize plants at 40 days after emergence compared to un-inoculated control. Qureshi et al. (2013) showed that the genus Rhizobium is an effective plant growth promoter in maize cultivars, due to its ability to improve the photosynthetic rate, up to $21 \%$. In addition, an increase in plant height and dry matter production was observed, these traits were attributed to the ability of Rhizobium strains to produce phytohormones. On the other hand, although there are few reports about maize growth promotion by Advenella (Espinoza-Victoria et al., 2009; Singh et al., 2014), this study shows that it can improve maize plant height from the first stages of development (Figure 4), besides increasing the dry matter content of maize.
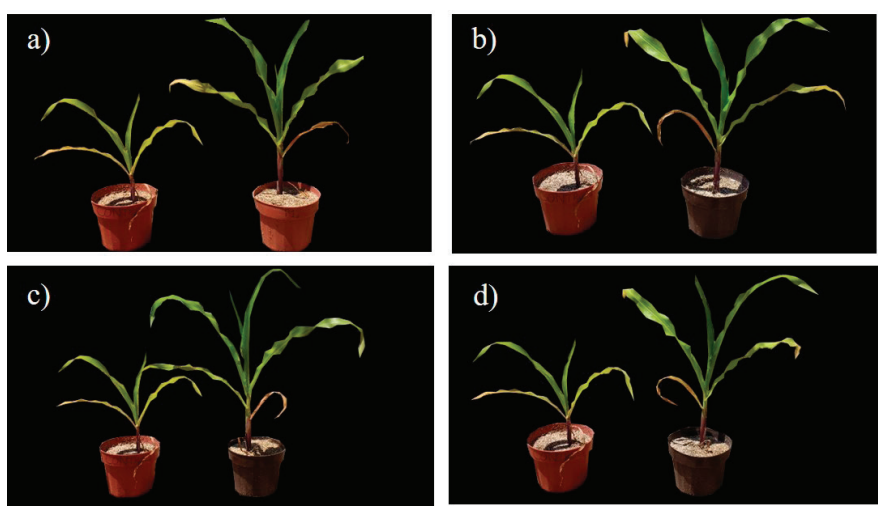

Figure 4. Effect of PGPB inoculation (right) on maize plant growth compared with un-inoculated plants (left). a) Advenella incenata 22A67, b) Bacillus sp. 13B41, c) Rhizobium pusense 31B11, d) Pantoea dispersa 22B45.

Figura 4. Efecto de la inoculación de PGPB (derecha) sobre el crecimiento de la planta de maíz en comparación con plantas no inoculadas (izquierda). a) Advenella incenata 22A67, b) Bacillus sp. 13B41, c) Rhizobium pusense 31B11, d) Pantoea dispersa 22B45. 


\section{CONCLUSION}

Plant growth-promoting bacterial strains studied here showed significant plant growth promoting traits in maize plants (root weight, plant height, number of leaves, stem thickness), under greenhouse conditions compared to the un-inoculated plants; however, these beneficial effects were similar among strains. Thus, Rhizobium pusense 31B11, Pantoea dispersa 22B45, Bacillus sp. 13B41, and Advenella incenata 22A67, isolated from the Yaqui Valley, are promising bacterial strains to be evaluated in field trials in this area or in others with similar edaphoclimatic conditions, to test their ability to improve grain yield in maize, so that they can be used as native microbial inoculants for sustainable agriculture.

\section{ACKNOWLEDGMENTS}

To the Instituto Nacional de Investigaciones Forestales, Agricolas y Pecuarias (INIFAP) for financial support through Project 2315932912 "Isolation and characterization of promising microorganisms to improve maize crop in southern Sonora and northern Sinaloa". And to the Consejo Nacional de Ciencia y Tecnología (CONACYT) for providing a fellowship (605488) to Carlos Fernando Amezquita Aviles.

\section{REFERENCES}

Abiala, M. A., Odebode, A. C., Hsu, S.F. and Blackwood, C. B. 2015. Phytobeneficial properties of bacteria isolated from the rhizosphere of maize in southwestern Nigerian soils. Applied and Environmental Microbiology, 81: 4736-4743.

Agbodjato, N. A., Noumavo, P. A., Adjanohoun, A., Agbessi, L. and Baba-Moussa, L. 2016. Synergistic effects of plant growth promoting rhizobacteria and chitosan on in vitro seeds germination, greenhouse growth, and nutrient uptake of maize (Zea mays L.). Biotechnology Research International, 2016:1-11.

Ahemad, M. and Kibret M. 2014. Mechanisms and applications of plant growth promoting rhizobacteria: current perspective. Journal of King Saud University-Science, 26: 1-20.

Alexander, D. Z. and Zuberer D. A. 1991. Use of chrome azurol S reagents to evaluate siderophore production by rhizosphere bacteria. Biology and Fertility of Soils, 12:39-45.

Cohn, F. 1872. Untersuchungen Über Bakterien. Beitrage zur Biologie Pflanz, 1: 1127-1224.

Chauhan, H., Bagyaraj, D. J., Selvakumar, G. and Sundaram, S. P. 2015. Novel plant growth promoting rhizobacteriaProspects and potential. Applied Soil Ecology, 95: 38-53.

Croft, H., Chen, J. M., Luo, X., Bartlett, P., Chen, B. and Staebler, R. M. 2016. Leaf chlorophyll content as a proxy for leaf photosynthetic capacity. Global Change Biology, 23: 35133524.

de los Santos-Villalobos, S., Barrera-Galicia, G. C., MirandaSalcedo, M. A. and Peña-Cabriales, J. J. 2012. Burkholderia cepacia XXVI siderophore with biocontrol capacity against Colletotrichum gloeosporioides. World Journal of Microbiology \& Biotechnology, 28: 2615-2623.

de los Santos-Villalobos, S., Parra-Cota, F. I., Herrera-Sepúlveda, A., Valenzuela-Aragón, B. and Estrada-Mora, J. 2018 Collection of edaphic microorganisms and native endophytes to contribute to national food security. Revista Mexicana de Ciencias Agrícolas, 9: 191-202.

de los Santos-Villalobos, S., Robles, R. I., Parra-Cota, F. I., Larsen, J., Lozano, P. and Tiedje, J. M. 2019. Bacillus cabrialesii sp. nov., an endophytic plant growth promoting bacterium isolated from wheat (Triticum turgidum subsp. durum) in the Yaqui Valley, Mexico. International Journal of Systematic and Evolutionary Microbiology, 69: 3939-3945.

de Souza, R., Ambrosini, A. and Passaglia, L. 2015. Plant growthpromoting bacteria as inoculants in agricultural soils. Genetics and Molecular Biology, 38: 401-419.

Duca, D., Lorv, J., Patten, C. L., Rose, D. and Glick, B. R. 2014. Indole-3-acetic acid in plant-microbe interactions. Antonie Van Leeuwenhoek, 106: 85-125.

Dutta, S. and Podile, A. R. 2010. Plant growth promoting rhizobacteria (PGPR): the bugs to debug the root zone. Critical Reviews in Microbiology, 36: 232-234.

Dworking, M. and Foster, J. W. 1958. Experiments with some microorganisms which utilize ethane and hydrogen. Journal of Bacteriology, 75: 592-602.

Espinosa-Victoria, D., López-Reyes, L. and La Cruz-Benítez, D. 2009. Uso del gen 16s rRNA para caracterización de bacterias solubilizadoras de fosfatos asociadas al maíz. Revista Fitotecnia Mexicana, 32: 31-37.

FAO. 2020. FAOSTAT. [Accessed 02 April 2020]. Available in: http://www.fao.org/faostat/en/\#data/QC

Festa, S., Coppotelli, B., Morelli, I. 2016 Comparative bioaugmentation with a consortium and a single strain in a phenanthrene-contaminated soil: Impact on the bacterial community and biodegradation. Applied Soil Ecology, 98: 8-19.

García-Meléndez, M., Zárate-Camargo, G., Meza-Contreras, J. J., Herrera-Sepúlveda, A., De los Santos-Villalobos, S. and ParraCota, F. I. 2017. Abiotic stress tolerance of microorganisms associated with oregano (Origanum vulgare L.) in the Yaqui Valley, Sonora. Open Agriculture, 2: 260-265.

Glick, B. R. 2012. Plant Growth-Promoting Bacteria: Mechanisms and applications. Scientifica, 2012:1-15.

Glickmann, E. and Dessaux, Y. 1995. A critical examination of the specificity of salkowski reagent for indolic compounds produced by phytopathogenic bacteria. Applied and Environmental Microbiology, 61: 793-796.

Hussain, M., Mehmood, S., Zahir, Z. A., Naveed, M., Imran, M., Ahmad, I., Ahmed, N. and Nawaz, H. 2016. Modulating nutrition, physiology, and production of maize through Rhizobium phaseoli and Mesorhizobium ciceri inoculation under drought stress conditions. 7 International Conference on Water Resources and Arid Environments. pp. 549-559. Riyadh, Saudi Arabia.

Kaur, G. and Reddy, M. S. 2013. Phosphate solubilizing rhizobacteria from an organic farm and their influence on the growth and yield of maize (Zea mays L). Journal of General and Applied Microbiology, 59: 295-303.

Kennedy, A. C. 1999. Bacterial diversity in agroecosystems. Agriculture, Ecosystems \& Environment, 74: 65-76.

Kobayashi, T. and Nishizawa, N. K. 2012. Iron uptake, translocation, and regulation in higher plants. Annual Review of Plant Biology, 63: 131-52.

Kumar, A., Maurya, B. R. and Raghuwanshi, R. 2014. Isolation and characterization of PGPR and their effect on growth, yield and nutrient content in wheat (Triticum aestivum L.). Biocatalysis and Agricultural Biotechnology, 3: 121-128. 
Kumar, S., Stecher, G., and Tamura, K. 2016. MEGA7: Molecular Evolutionary Genetics Analysis version 7.0 for bigger datasets. Molecular Biology and Evolution, 33:1870-1874.

McCullough, E. B. and Matson, P.A. 2016. Evolution of the knowledge system for agricultural development in the Yaqui Valley, Sonora, Mexico. Proceedings of the National Academy of Sciences, 113: 4609-4614.

Mehboob, I., Zahir, Z. A., Arshad, M., Tanveer, A. and Khalid, M. 2012. Comparative effectiveness of different Rhizobium sp. for improving growth and yield of maize (Zea mays L.). Soil and Environment, 31:37-46.

Meza-Montenegro, M. M., Gandolfi, A. J., Santana-Alcántar, M. E., Klimecki, W. T., Aguilar-Apodaca, M. G., Del Río-Salas, R. and Meza-Figueroa, D. 2012. Metals in residential soils and cumulative risk assessment in Yaqui and Mayo agricultural valleys, northern Mexico. Science of the Total Environment, 433: 472-481.

Montañez, A., Blanco, A. R., Barlocco, C., Beracochea, M. and Sicardi, M. 2012. Characterization of cultivable putative endophytic plant growth promoting bacteria associated with maize cultivars (Zea mays L.) and their inoculation effects in vitro. Applied Soil Ecology, 58: 21-28.

Naveed, M., Qureshi, M., Zahir, Z., Hussain, M., Sessitsch, A. and Mitter, B. 2014. L-Tryptophan-dependent biosynthesis of indole-3-acetic acid (IAA) improves plant growth and colonization of maize by Burkholderia phytofirmans PsJN. Annals of Microbiology, 65: 1381-1389.

Onyia, C. E. and Anyanwu, C. U. 2013. Comparative study on solubilization of tricalcium phosphate (TCP) by phosphate solubilizing fungi (PSF) isolated from Nsukka pepper plant rhizosphere and root free soil. Journal of Yeast and Fungal Research, 4: 52-57.

Pande, A., Pandey, P., Mehra, S., Singh, M. and Kaushik, S. 2017. Phenotypic and genotypic characterization of phosphate solubilizing bacteria and their efficiency on the growth of maize. Journal of Genetic Engineering and Biotechnology, 15: 379-391.

Parra-Cota, F. I., Peña-Cabriales, J. J., de los Santos-Villalobos, S., Martínez-Gallardo, N. A. and Délano-Frier, J. P. 2014. Burkholderia ambifaria and $B$. caribensis promote growth and increase yield in grain amaranth (Amaranthus cruentus and $A$. hypochondriacus) by improving plant nitrogen uptake. PloS one, 9(2).

Qureshi, M. A., Shahzad, H., Imran, Z., Mushtaq, M., Akhtar, N., Ali, M. A. and Mujeeb, F. 2013. Potential of Rhizobium species to enhance growth and fodder yield of maize in the presence and absence of I-tryptophan. Journal of Animal and Plant Sciences, 23: 1448-1454.

Sansinenea, E. 2019. Bacillus spp.: As plant growth-promoting bacteria. In: Secondary Metabolites of Plant Growth Promoting Rhizomicroorganisms. Singh, H. B., Keswani, C., Reddy, M. S., Royano, E. S., García-Estrada, C.U. (Eds), pp. 225237. Springer, Singapore.

Setter, T. L. and Meller, V. H. 1984. Reserve carbohydrate in maize stem: [14C] glucose and [14C] sucrose uptake characteristics. Plant Physiology, 75: 617-622.
Seyed Sharifi, R., Khalilzadeh, R. and Soltanmoradi, S. 2017. Evaluation effects of mycorrhizal fungi (AM) and nano zinc oxide on seed yield and dry matter remobilization of wheat (Triticum aestivum L.) under salinity stress. Journal of Crop Nutrition Science, 3: 61-69.

Shahzad, S. M., Khalid, A., Arshad, M., Khalid, M. and Mheboob, I. 2008. Integrated use of plant growth promoting bacteria and P-enriched compost from improving growth, yield and nodulation of chickpea. Pakistan Journal of Botany, 40: 1735-1441.

Sharon, J. A., Hathwaik, L. T., Glenn, G. M., Imam, S. H. and Lee, C. C. 2016. Isolation of efficient phosphate solubilizing bacteria capable of enhancing tomato plant growth. Journal of Soil Science and Plant Nutrition, 16: 525-536.

SIAP-SADER. Servicio de Información Agroalimentaria y Pesquera (SIAP). [Accessed March 31 2020]. Available in: http://nube.siap.gob.mx/cierre_agricola/

Silva, K., Perin, L., Gomes, M. D., Baraúna, A. C., Duarte, G. M., Mosqueira, C. A., da Costa, I. B., O’hara, G. and Zilli, J. É. 2016. Diversity and capacity to promote maize growth of bacteria isolated from the Amazon region. Acta Amazonica, 46: 111 118.

Singh, P., Kumar, V. and Agrawal, S. 2014. Evaluation of phytase producing bacteria for their plant growth promoting activities. International Journal of Microbiology, 2014: 1-7.

Spaepen, S. and Vanderleyden, J. 2011. Auxin and plant-microbe interactions. Cold Spring Harbor Perspectives in Biology, 3: a001438.

Trabelsi, D. and Mhamdi, R. 2013. Microbial inoculants and their impact on soil microbial communities: a review. BioMed Research International, 2013.

Valenzuela-Aragon, B., Parra-Cota, F. I., Santoyo, G., ArellanoWattenbarger, G. L. and de los Santos-Villalobos, S. 2019. Plant-assisted selection: a promising alternative for in vivo identification of wheat (Triticum turgidum L. subsp. Durum) growth promoting bacteria. Plant and soil, 435: 367-384.

Villarreal-Delgado, M. F., Villa-Rodríguez, E. D., Cira-Chávez, L. A., Estrada-Alvarado, M. I., Parra-Cota, F. I. and de los Santos-Villalobos, S. 2018. El género Bacillus como agente de control biológico y sus implicaciones en la bioseguridad agrícola. Revista Mexicana de Fitopatología, 36: 95-130.

Viruel, E., Erazzú, L., Calsina, L., Ferrero, M., Lucca, M. and Siñeriz, F. 2014. Inoculation of maize with phosphate solubilizing bacteria: effect on plant growth and yield. Journal of Soil Science and Plant Nutrition, 14: 819-831.

Wang, J., Li, R., Zhang, H., Wei, G. and Li, Z. 2020. Beneficial bacteria activate nutrients and promote wheat growth under conditions of reduced fertilizer application. BMC Microbiology, 20: 1-12.

Weisburg, W., Barns, S., Pelletier, D. and Lane, D. 1991. 16S Ribosomal DNA amplification for phylogenetic study. Journal of Bacteriology, 173: 697-703. 